\title{
COVID-19: COSTLY SIGNALS AND ENTREPRENEURIAL BRICOLAGE FOR SMES SURVIVABILITY FROM THE VIEW OF THE FINANCIAL-BASED CROWDFUNDING IN MALAYSIA
}

\author{
SITI FATIMAH MOHD KASSIM* AND KALSOM ABD. WAHAB
}

Faculty of Economics and Muamalat, Universiti Sains Islam Malaysia, Bandar Baru Nilai, 71800, Nilai, Negeri Sembilan, Malaysia.

*Corresponding author: anafatimah315@raudah.usim.edu.my

Submitted final draft: 18 February 2021

Accepted: 5 March 2021

http://doi.org/10.46754/jbsd.2021.09.001

\begin{abstract}
Crowdfunding has altered the entrepreneurial funding landscape in Malaysia. Statistics generated by Securities Commission of Malaysia indicates that a number of small-and-medium-sized enterprises (SMEs) have benefitted from the equity (ECF) and peer-to -peer (P2P) lending in the crowdfunding markets. The recent COVID-19 pandemic has badly affected many economic sectors, especially SMEs. They are thus forced to adapt to the "new normal" in order to sustain continued growth and create shared value. The objective of this study is to explore the significance of costly signals, which attempts to explain instances of public generosity in which individuals incur costs without any immediate benefits or entrepreneurial bricolage, creating something from nothing by making do and applying combinations of resources at hand to new problems and opportunities to aid SMEs in obtaining financial assistance from the online investors. This is a conceptual study that refers to previous literature on costly signals and entrepreneurial bricolage. This study also used a content analysis technique where the equity crowdfunding platform's website during movement control order (MCO) from $18^{\text {th }}$ March, 2020 to $18^{\text {th }}$ November, 2020 was examined to gather the information. The contents related to ECF campaigns on the platform's website was extracted and used in the analysis. However, due to limited available literature on ECF and P2P on the available platforms, this study focused solely on the ECF campaigns hosted on the PitchIn Platform Sdn Bhd's website. Prompt and innovative decisions are crucial especially during the pandemic. Entrepreneurs need to be able to highlight vital information for stakeholders and potential investors. ECF platforms also need to be able to present and highlight their information as this could reduce the asymmetry of information. In this manner, both the platform and the entrepreneur will benefit from the growth of the crowdfunding market in Malaysia. As the sustainability of the crowdfunding ecosystem in Malaysia depends on the sustainability of the entrepreneurs and the platform providers policy measures by the government should not be restricted merely to eliminating cash flow burdens, but should also include the wider entrepreneurial landscape to improve its efficiency. The government needs to have real-time information so that any uncertainty facing the entrepreneurs can be handled accordingly. This study also suggests future research to further investigate the importance of costly signals under crowdfunding umbrella.
\end{abstract}

Keywords: Costly signals, technological advancement, entrepreneurial bricolage, platform providers, social networks.

\section{Introduction}

The COVID-19 pandemic has triggered several reactionary measures and innovations in the global marketplace including, changes to preferences in the existing entrepreneurial ecosystem affecting various sectors of the economy (Leung et al., 2020). Entrepreneurial robustness responds to the crisis in different ways based on several internal and external factors. The former internal factors include the firm's human demography, its size, age, and the strategies employed. The latter external 
factors influence the firm's response towards the crisis include government intervention and technological advancement.

The current execution and continuation of the Movement Control Order (MCO) and Work from Home (WFH) initiative by the Malaysian Government has disturbed both individuals and businesses. As banking and other financial institutions are notably less "user-friendly" in times of crisis, their inaccessibility causes further problems to all parties including SMEs (Kuckertz et al., 2020).

Following this scenario, crowdfunding has been identified as a more agile, nimble and reliable alternative to conventional banking and finance options to reduce the gap in funding faced by firms in the wake of the COVID-19 crisis (Brown et al., 2020; Securities Commission Malaysia, 2020).

The "new normal" economic environment requires individuals, public and private organizations to adapt to changes as quickly as possible to mitigate the damage done by the loss of business in the wake of the pandemic. Some of the drastic measures adopted by affected organizations include ceasing operations, cutting down on manpower, adapting and innovating for survival (Deschryvere et al., 2020).

These efforts could temper the operating costs and cause a deviation in the normal practices which could affect the overall performance of the firms (Wenzel et al., 2020). In reality, as the crisis happened quickly and without warning (Bogle \& Sullivan, 2009), the ability to make sound decisions quickly is crucial so that businesses are not caught flatfooted (Kuckertz et al., 2020).
A check and balance strategy for causes and actions is essential in order to curb business loss during the crisis (Ramadani et al., 2017). The ability of the SMEs to provide convincing signals could encourage and motivate both existing and potential funders to participate in a new funding campaign. This requires quality signals which are capable of reducing information asymmetry, and vagueness that fund-raisers transmit to the fund providers in the crowdfunding market (Di Pietro et al., 2020).

\section{Types of Crowdfunding}

Pazowski and Czudec (2014) have outlined several types of crowdfunding with the four most familiar being donation-based. The other types of crowdfunding are reward-based, P2P lending-based and equity-based crowdfunding.

The donation-based and reward-based crowdfunding are also known as non-financial based crowdfunding, while equity-based and P2P lending-based crowdfunding are referred to as finance-based crowdfunding.

Equity-based crowdfunding refers to funding by investors in exchange for shares in the venture (Estrin et al., 2018; Freedman \& Nutting, 2015; Hagedorn \& Pinkwart, 2016; Tuomi \& Harisson, 2017). On the other hand, the P2P lending-based refers to funding received from investors that is treated as a debt and is subject to repayment of the principal amount and interest (Bruton et al., 2015). It involves an underwriting process (Morse, 2015). Table 1 summarises the types, the returns, and the motivations of the investor when engaging in crowdfunding activities. 
Table 1: Types of crowdfunding, returns and funder motivation

\begin{tabular}{|c|c|c|c|c|}
\hline $\begin{array}{c}\text { Types of } \\
\text { Crowdfunding }\end{array}$ & Donation & Reward & P2P Lending & Equity \\
\hline Form of contribution & Donation & $\begin{array}{l}\text { Donation/Pre- } \\
\text { purchase }\end{array}$ & Loan & Investment \\
\hline Form of return & $\begin{array}{l}\text { Intangible } \\
\text { benefits }\end{array}$ & $\begin{array}{c}\text { Reward \& } \\
\text { intangible benefits }\end{array}$ & $\begin{array}{c}\text { Repayment of } \\
\text { loan plus interest. } \\
\text { Socially motivated } \\
\text { lending is interest } \\
\text { free }\end{array}$ & $\begin{array}{l}\text { ROI in time if business } \\
\text { is making profit. } \\
\text { Rewards and intangible } \\
\text { benefits also attract } \\
\text { investors }\end{array}$ \\
\hline $\begin{array}{l}\text { Motivation of the } \\
\text { investors }\end{array}$ & $\begin{array}{l}\text { Intrinsic } \\
\text { and social } \\
\text { motivation }\end{array}$ & $\begin{array}{l}\text { Combination of } \\
\text { intrinsic, special } \\
\text { motivation and } \\
\text { reward }\end{array}$ & $\begin{array}{c}\text { Combination of } \\
\text { intrinsic, social } \\
\text { and financial } \\
\text { motivation }\end{array}$ & $\begin{array}{c}\text { Combination of } \\
\text { intrinsic, social and } \\
\text { financial motivation }\end{array}$ \\
\hline
\end{tabular}

Source: Pazowski \& Czudec (2014)

\section{Definitions of Crowdfunding}

In general, crowdfunding refers to the collection of a small portion of money from the public via the Internet (Green et al., 2015). Making use of Internet savvy individuals can be advantageous to crowdfunding campaigns as attractive appeals and advertisements posted on social media platforms via online applications such as Instagram, Facebook, WhatsApp and others help the initiator attract citizens attention and draw in donations, provide proper information on the crowdfunding initiative, and the kinds of reward donators or investors will get in a timely manner (Baeck \& Collins, 2013; Gierczak et al., 2016; 2015).

Freedman and Nutting (2015) posit that the existence of social media enables the collection of small amounts of money from many people, especially when the project has social value. Thus, it is also known as the "social model of financing" (Brzozowska, 2013) or "collective financing" (Biancone et al., 2019).

According to Beck (2017), crowdfunding is a manifestation of globalisation and the Internet's openness where a group of people share resources with others in the community that have the same objectives, mission and obligations. Additionally, entrepreneurial internalisation is possible in a crowdfunding setting (Cumming \& Johan, 2017).

Additionally, crowdfunding has the potential to overcome the traditional issues involved in obtaining funding for entrepreneurial ventures and encourages entrepreneurs to go beyond the typical entrepreneur's conventional approach to doing business. Furthermore, crowdfunding promotes new business ideas and develops significant skills and knowledge. Moreover, crowdfunding demonstrates trust as a factor that increases public confidence (Swart \& Milner, 2015).

\section{Financial-based Crowdfunding in Malaysia}

The main actors in the crowdfunding ecosystem are the fundraiser or the project creator, the investors, and the platform provider. At present, there are no rules or regulations that bind donations and reward-based crowdfunding.

In contrast, financial-based crowdfunding which is also known as crowd-investing such as equity crowdfunding, peer-to-peer financing and property crowdfunding involve certain rules and regulation. Equity-based crowdfunding is realised when shares in the venture are replaced 
with money. This type of crowdfunding involves the transfer of ownership from firms to the investors.

On the other hand, peer-to-peer (P2P) lending entitles the firm to obtain a loan from investors and to pay back the principal plus interest as agreed. Hence, these serve as some of the reasons why financial-based crowdfunding is highly regulated in Malaysia (Securities Commission Malaysia, 2015).

Financial-based crowdfunding in Malaysia is governed by the Securities Commission Malaysia under the Guidelines on Regulation of Markets and section 34 of the Capital Markets and Services Act 2007 (CMSA) to facilitate equity crowdfunding platforms, especially with regard to the procedures to be followed and the way the crowdfunding is supposed to be conducted and the manner in which the fund operates.

The introduction of these guidelines made Malaysia the first country in Asia to have its own regulations for equity-based crowdfunding (Securities Commission Malaysia, 2016). However, the guidelines have been superseded by the Guidelines on Recognized Markets, revision series number SC-GL/6-2015 (R12016).

The revised guideline is to be read together with sub-division 4, division 2 of Part II CMSA in accordance with section 377 of the Capital Markets and Services Act 2007. Part F of the guideline specifically represents the additional requirements relating to a recognised market that is the crowdfunding platform. It consists of two chapters; Chapter 12 on equity crowdfunding platforms and Chapter 13 on peer-to-peer (P2P) lending or crowdfunding (Securities Commission Malaysia, 2016). This is to enhance the investment-related crowdfunding in order to safeguard the crowdfunding actors, especially investors, and to assure that this funding mechanism would benefit the SMEs (Securities Commission Malaysia, 2015).
The guideline requires that the operator or director must be proper and have the ability to operate an orderly, fair, and transparent market. As the operator plays a critical role in ensuring the confidence of the equity crowdfunding (ECF) platform, the guideline entrusts the operator with obligation to ensure the issuers' compliance with platform rules. The operator may deny an issuer access to its platform if it is of the view that the issuer or the proposed offering is not suitable for hosting on its platform.

The operator has to comply with the All-orNothing funding model (AON) where the money raised will be distributed to the issuer only if the funding goals are achieved. In case the money raised is below the campaign minimum target, then the money will be given back to those who have invested. The operator is also required to ensure that funds obtained from investors are safeguarded in a trust account until the funding goal is met. Under this framework, an eligible issuer can raise up to RM3 million within a 12-month period. Issuers will be able to tap on investments from retail, sophisticated and angel investors, subject to the investment limits as provided in the guidelines.

ECF investors are given a six-day cooling off period, within which they may withdraw the full amount of their investment. In addition, if there is any material adverse change relating to an issuer, the investors must be notified of such change. The investors will be given the option to withdraw their investment if they choose to do so within 14 days after the said notification.

\section{Financial-based Crowdfunding Platform Providers in Malaysia}

Known as registered market operators (RMO), the platform providers are differentiated based on the platforms' purpose. Table 2 represents the list of financial-based platform providers in Malaysia. 
Table 2: The platform providers: Recognized Market Operators (RMO)

\begin{tabular}{lll}
\hline Equity-based Crowdfunding & P2P Lending-based Crowdfunding & Real Estate-based Crowdfunding \\
\hline Ata Plus Sdn Bhd & Bay Smart Capital Ventures Sdn Bhd & EdgeProp Sdn Bhd \\
Crowdo Malaysia Sdn Bhd & B2B FinPal Sdn Bhd & \\
Crowdplus Sdn Bhd & Capsphere Services Sdn Bhd & \\
Eureeca SEA Sdn Bhd & Crowd Sense Sdn Bhd & \\
Ethis Ventures Sdn Bhd & Ethis Kapital Sdn Bhd & \\
FBM Crowdtech Sdn Bhd & FBM Crowdtech Sdn Bhd & \\
Fundnel Technologies Sdn Bhd & MicroLEAL Plt & \\
Leet Capital Sdn Bhd & Modalku Ventures Sdn Bhd & \\
MyStartr Sdn Bhd & Moneysave (M) Sdn Bhd & \\
Pitchin Platforms Sdn Bhd & Peoplender Sdn Bhd & \\
& QuicKash Malaysia Sdn Bhd & \\
\hline
\end{tabular}

Source: Securities Commission Malaysia (2020)

\section{The Obligations of RMO of Crowdfunding in Malaysia}

A crowdfunding platform provider is the ECF platform that operates a registered electronic facility (REF). To be legalized, the platform must be locally incorporated and fulfil the requirement stipulated in the Guidelines (Securities Commission Malaysia, 2020). Table 3 shows among the responsibilities of the RMO in crowdfunding markets;

Table 3: RMO obligations

\begin{tabular}{|c|c|c|}
\hline No. & Equity Crowdfunding & P2P Lending Crowdfunding \\
\hline 1 & $\begin{array}{l}\text { Carry out a due diligence exercise on prospective } \\
\text { issuers who plan to use its platform which include to } \\
\text { conduct background checks on the issuer to ensure } \\
\text { fit and properness of the issuer's board of directors, } \\
\text { officers, and controlling owner together with } \\
\text { verification of issuer business proposition. }\end{array}$ & $\begin{array}{l}\text { Ensure there is an efficient and transparent } \\
\text { risk scoring system in place relating to the } \\
\text { investment note or Islamic investment note. }\end{array}$ \\
\hline 2 & $\begin{array}{l}\text { Monitor the conduct of issuer and take action against } \\
\text { misconduct of the issuer. }\end{array}$ & $\begin{array}{l}\text { Carry out a risk assessment on prospective } \\
\text { issuers intending to use its platform. }\end{array}$ \\
\hline 3 & Carry out investor education programs. & $\begin{array}{l}\text { Ensure the issuer's disclosure document } \\
\text { lodged with the P2P operator is verified for } \\
\text { accuracy and made accessible to investors } \\
\text { through the P2P platform. }\end{array}$ \\
\hline 4 & $\begin{array}{l}\text { Ensure the issuer's disclosure document lodged with } \\
\text { the ECF operator is verified for accuracy and made } \\
\text { accessible to investors through the platform. }\end{array}$ & $\begin{array}{l}\text { Inform investors of any material adverse } \\
\text { change to the issuer's proposal as set out under } \\
\text { paragraph } 14.12 \text {. }\end{array}$ \\
\hline 5 & $\begin{array}{l}\text { Inform investors of any material adverse change to } \\
\text { the issuer's proposal including the detection of false } \\
\text { and misleading statement, omission of important } \\
\text { information to the disclosure document, and anything } \\
\text { concerning the offering and the issuer. }\end{array}$ & $\begin{array}{l}\text { Have in place processes or policies to manage } \\
\text { any default by issuers including using its best } \\
\text { endeavors to recover amounts outstanding to } \\
\text { investors. }\end{array}$ \\
\hline
\end{tabular}


6 Monitor issuers to ensure that the fundraising limits In addition to the provision as set out in imposed on the issuer are not breached. subparagraph 3.01(j), ensure that its rules set out a rate of financing that is not more than eighteen (18) per cent per annum. A P2P operator must consult the $\mathrm{SC}$ if it wishes to impose a rate of financing that is more than 18 per cent per annum.

7 Monitor investors to ensure that the investment limits Conduct background checks on the issuer imposed on the investors are not breached. to ensure fit and properness of the issuer, its board of directors, senior management and controller.

8 Obtain and retain the self-declared risk Verify the business proposition of the issuer. acknowledgement forms from the investors prior to them investing on an ECF platform.

9 Have in place processes to monitor anti-money Carry out assessment on the issuer's laundering requirements. creditworthiness.

10 Ensure privacy of information is maintained in accordance with the Personal Data Protection Act 2010.

11 Establish and maintain the designated trust accounts relating to the fundraising on its platform in the licensed institution. The money will be disbursed when the target amount is met, no material changes during the offer period, and after the six business days' cooling-off period had passed.

Source: Securities Commission Malaysia (2020)

Platforms or intermediaries, mediators, and middlemen reflect the same primary purpose that is connecting others. Intermediation can be found in the financial industry, takaful and insurance industry, marketing, manufacturing, advertisement, technology, and many others. It refers to connecting one party with another party.

Howells (2006) investigated the intermediation and found that it grew as time passed. Intermediaries diversify from focusing on certain specialisation to the acquisition of new required skills and specialties, thus created value and improved vitality within the system. Intermediaries function to not only connect parties but to also enhance them by promoting new opportunities and passions. Evaluating the impact of intermediary innovation is difficult given its direct and indirect effects on the value chain of businesses.

However, the growth of the number and distance of perpetrators in the system denies the benefits they make to their customers and to the whole system of innovation. Nevertheless, the richness and success of intermediation in the overall system can potentially create institutional inertia, which can cause problems in the strength and longevity of the system in the long run (Van der Meulen \& Rip, 1998).

According to Haas, Blohm and Leimeister (2014), it is reasonable to investigate the crowdfunding platforms' potential as intermediaries since research on crowdfunding platforms is still lacking. Hass et al. (2014) found that intermediaries' value propositions differ depending on the crowdfunding models 
(i.e., hedonism as reward, altruism as donation, and profit). On the other hand, Salomon (2016) views the emergence of crowdfunding platforms as the manifestation of declining support from venture capital (VC) industries and private equity (PE) funds. This suggests that VCs and PEs are abandoning the early-stage entrepreneurial market as it is difficult to identify sound startup projects to build a successful portfolio. Hence, they merely concentrate on the existing and growing businesses that already have worthwhile products and stability in the market (Lindstrom \& Olofsson, 2001).

Financial-based Crowdfunding: Maximum Fundraising Limits and Additional Funding Assistance

The Securities Commission Malaysia governs the activities of financial-based crowdfunding to ensure it remains relevant as an online funding resource for entrepreneurial ventures, the public and private sectors. Initially, the maximum amount an issuer can raise through the ECF platform is RM5 million. This amount excludes the issuers' own capital contribution and any funding obtained through other sources. However, in every 12-month period, an issuer can only raise up to RM3 million irrespective of the number of projects and the issuer may seek another RM2 million the following year (Securities Commission Malaysia, 2016).

However, the maximum amount has been raised from RM5 million to RM10 million for the equity-based campaign. The P2P lending campaign, in contrast, is not subject to the maximum fundraising limit gazette. However, P2P lending campaigns are not allowed to retain the extra money that exceed the campaign's initial funding goal or amount. In cases where the $\mathrm{P} 2 \mathrm{P}$ campaign manages to raise more than the required amount, the excess amount must be given back to the funder. Starting from year 2019 , both platforms are now allowed to set up secondary trading (Securities Commission
Malaysia, 2020; Gomez, 2020; Kuek, 2020). This is due to the micro, small and medium enterprises interest on these funding avenues.

On top of that, the Malaysia Co-Investment Fund (MyCIF) for eligible ECF and P2P campaigns has been introduced to encourage investors and government collaboration to grow SMEs in Malaysia. The MyCIF was established with RM50 million from existing grants to be coinvested in SMEs with private investors through ECF and P2P crowdfunding platforms (Farah Adilla, 2017). The ratio is set at 1:4, meaning that for every four Malaysia ringgit raised from ECF, the MyCIF will invest RM1 and the maximum cap is limited to RM500,000. Due to the pandemic and to provide further liquidity in entrepreneurial funding, the government has increased the maximum cap for MyCIF to RM1 million with the current ratio of 1:2. However, the current maximum cap was only set up to the month of September 2020 (Fong, 2020), and has been extended until the end of December 2020.

\section{The Costly Signals in Financial-based Crowdfunding}

According to Di Pietro, Grilli and Masciarelli (2020), the equity crowdfunding fundraisers that display their ventures' previous achievement, particularly the financial realisation (costly signals), could reduce the ambiguity and asymmetric information among the crowd. This will eventually increase their chance in securing funding. In contrast, the fundraisers that merely display their future planning and anticipate profitability (costless signals) will not attract the crowd's attention. However, the crowd does not penalise the campaigns that anticipate future achievements if they are combined with a profound innovation strategy.

It is significant to provide good signals to the potential funders especially when it involves the start-ups or new firms (Baum \& Silverman, 2004; Mollick, 2014). Table 4 shows the costly signals from other currently available literature. 
Table 4: Costly signals

\begin{tabular}{|c|c|c|c|}
\hline No. & Category & Costly Signals & Citation \\
\hline 1 & & Patents & Hsu \& Ziedonis (2013) \\
\hline 2 & & Board governance & Sanders \& Boivie (2004) \\
\hline 3 & & Business model & $\begin{array}{l}\text { Ahlers et al. (2015), Lukkarinen et } \\
\text { al. (2016) }\end{array}$ \\
\hline 4 & & Product certifications & $\begin{array}{l}\text { Ahlers et al. (2015), Bapna et al. } \\
\text { (2017) }\end{array}$ \\
\hline 5 & & $\begin{array}{l}\text { Words used in } \\
\text { crowdfunding campaigns }\end{array}$ & Mollick (2014) \\
\hline 6 & Strategy & $\begin{array}{l}\text { Substantive information, } \\
\text { press release }\end{array}$ & Steigenberger \& Wilhelm (2018) \\
\hline 7 & & Financial statement & Di Pietro et al. (2020) \\
\hline 8 & & Marketing intensity & Bae et al. (2017) \\
\hline 9 & & $\begin{array}{l}\text { Public communication } \\
\text { (open dialog) }\end{array}$ & Behl et al. (2020) \\
\hline 10 & & $\begin{array}{l}\text { Quality financial } \\
\text { reporting, audit quality }\end{array}$ & $\begin{array}{l}\text { Chen et al. (2017), Shahzad et al. } \\
\text { (2019) }\end{array}$ \\
\hline 11 & & $\begin{array}{l}\text { Announce share } \\
\text { repurchases and } \\
\text { repurchase }\end{array}$ & Bhattacharya \& Dittmar (2003) \\
\hline 12 & & $\begin{array}{l}\text { Founding team's } \\
\text { demography }\end{array}$ & $\begin{array}{l}\text { Ahlers et al. (2015), Bernstein et al. } \\
\text { (2017), Lim \& Busenitz (2020) }\end{array}$ \\
\hline 13 & $\begin{array}{l}\text { Founder \& Top Management } \\
\text { Team Demographic }\end{array}$ & $\begin{array}{l}\text { Founder's education } \\
\text { background }\end{array}$ & Baum \& Silverman (2004) \\
\hline 14 & & $\begin{array}{l}\text { Top management team's } \\
\text { demography }\end{array}$ & Baum \& Silverman (2004) \\
\hline 15 & & Third party affiliations & Plummer et al. (2016) \\
\hline 16 & & $\begin{array}{l}\text { External network } \\
\text { (founder's networks) }\end{array}$ & Liao et al. (2015) \\
\hline 17 & & $\begin{array}{l}\text { Internal network } \\
\text { (entrepreneur-platform } \\
\text { provider) association }\end{array}$ & Helmer (2014) \\
\hline 18 & Networks \& Affiliations & $\begin{array}{l}\text { Participation of expert } \\
\text { investors }\end{array}$ & Kim \& Viswanathan (2019) \\
\hline 19 & & $\begin{array}{l}\text { Early investor } \\
\text { engagement }\end{array}$ & Vismara (2018) \\
\hline 20 & & Third party endorsement & $\begin{array}{l}\text { Courtney et al. (2017), Kleinert et } \\
\text { al. (2020) }\end{array}$ \\
\hline 21 & & Affiliations with investors & Woköck (2019) \\
\hline 22 & & Social communication & Dessalles (2014) \\
\hline
\end{tabular}

(Author's Illustration) 
These signals can be categorised into three main themes; the strategy, the founder and top management team (TMT) demographic and networks and affiliations. These signals are vital in order to attract to and alert potential funders of fundraising activities, especially during the pandemic. COVID-19 has badly affected SMEs and nascent ventures by drastically reducing their financial resources. For instance, in China, a comparison between investment availability from the first quarter of 2019 and 2020 shows a more than $50 \%$ reduction in investments. In essence, COVID-19 has changed investors' reactions towards equity crowdfunding activities (Brown \& Rocha, 2020).

Thus, quality costly signals would increase investors' satisfaction and willingness to participate in fundraising for crowdfunding activities. However, the costly signals incur substantial amounts of expenditure. This is a reason why start-ups prefer costless signals rather than costly signals.

In certain circumstances, such as innovation strategy, costless signals such as cheap talk has also impacted a firm's investment efficiency (Di Pietro et al., 2020). Costless signals surely involve investors' interference (Bhattachary \& Dittmar, 2003).

\section{Entrepreneurial Bricolage}

Entrepreneurial bricolage behaviours tend to trigger resolution finding among entrepreneurs in order to solve any issues arising (Tsilika et al., 2020). Bricolage is regarded as a prominent tool in a resource scarce environment to find innovative new technologies and new ventures (Baker \& Nelson, 2005; Di Domenico et al., 2010; Halme et al., 2012). Bricolage behaviours in entrepreneurship are usually present in each and every activity of the venture, meaning that entrepreneurial bricolage is not merely utilised for a specific management approach. For instance, ventures use their networks to create new opportunities despite the limitations they face under the network bricolage (Chang \& Webster, 2019; Mahajan, 2013).
On top of that, financial bricolage makes the entrepreneur creative with the use of the resources available at hand to obtain funding assistance using crowdfunding for example (Kariv \& Coleman, 2015).

The concept of bricolage means to take advantage of entrepreneurial opportunities, therefore it is an internal and external feature. Internal bricolage refers to the entrepreneur's characteristics, experience and knowledge of the market, customers' issues and other attributes that will help the entrepreneurs combat issues and capture emerging opportunities.

Meanwhile, external bricolage, indicates the entrepreneur's behaviour and willingness to fully utilise external resources available (Vanevenhoven et al., 2011). Nevertheless, both serve the purpose of creating new combinations of resource inputs with the intent to foster the company's performance (Kariv \& Coleman, 2015), the continued creation of shared value (Dominguez et al., 2020) and growth (Battaglia et al., 2020).

Previous studies acknowledge bricolage as a good corporate strategy, especially for companies with resource constraints (Baker, 2007; Baker et al., 2003; Senyard et al., 2011).

The three characteristics of bricolage include:

- bias in action when confronting opportunities and tackling crisis;

- creating value to futile resources; and

- creatively conjoining resources for greater outcomes (Baker \& Nelson, 2005).

These include, for instance, innovation (Anderson \& Kupp, 2008; Garud \& Karnøe, 2003). However, Desa and Basu (2013) argue that further research should be done to examine the effect of bricolage on performance, and specifically, innovation. Therefore, in view of the current pandemic, it is vital for ventures to continue (Stenholm \& Renko, 2016) and improve business models (Ketchen \& Craighead, 2020). 


\section{Research Methodology}

The research method used in this study is a qualitative analysis of the contents on the ECF and $\mathrm{P} 2 \mathrm{P}$ crowdfunding platforms during $\mathrm{MCO}$ from $18^{\text {th }}$ March, 2020 to $18^{\text {th }}$ November, 2020. However, due to limited information available on these platforms, this study focused on Pitchin Platform Sdn Bhd (PitchIN)'s crowdfunding services and its website.

PitchIN is one of the leading ECF platforms in Malaysia. The objective of this study is to explore the significance of costly signals and entrepreneurial bricolage in aiding the SMEs to obtain the financial assistance from the online investors.

\section{Results}

The Prologue of Financial-based Crowdfunding Activities during the Pandemic

Table 5 below demonstrates the ECF achievement as of $31^{\text {st }}$ March, $30^{\text {th }}$ June and $30^{\text {th }}$
September, 2020. Fundraisers engaged with the ECF platform as they have the shares to offer to investors. The number of successful fundraisers was 113 and the number of successful campaigns was 119.

More than RM120 million had been raised as of September 2020. Investments of RM500,000 and below represented $41 \%$ of the total amount raised. ECF activities also showed that the major investors were from the retail category and $46 \%$ of the investors who participated in the ECF campaigns were below 35 years old.

In Malaysia, retail investors can invest not more than RM50,000 a year and are subject to a maximum of RM5,000 per issuer. However, angel investors can invest in financial-based crowdfunding to the tune of RM500,000 per year and sophisticated investors face no restrictions on the amounts they can invest (Securities Commission Malaysia, 2016).

Table 5: Equity crowdfunding statistics from March 2020 to September 2020

\begin{tabular}{|c|c|c|c|c|}
\hline & \multirow{2}{*}{ Equity Crowdfunding } & \multicolumn{3}{|c|}{ Crowdfunding Statistics as at } \\
\hline & & $31^{\text {st }}$ March 2020 & $30^{\text {th }}$ June 2020 & $30^{\text {th }}$ Sept 2020 \\
\hline 1 & Campaigns and Issuers & & & \\
\hline $\mathrm{i}$ & Successful Campaigns & 94 & 106 & 119 \\
\hline ii & Amount Raised (RM) & 90.36 mil & 110.26 mil & $129.64 \mathrm{mil}$ \\
\hline iii & Successful Issuers & 91 & 102 & 113 \\
\hline \multirow[t]{5}{*}{ iv } & Distribution & & & \\
\hline & RM500k and below & $48 \%$ & $42 \%$ & $41 \%$ \\
\hline & $>$ RM $500 \mathrm{k}-\mathrm{RM} 1.5 \mathrm{~m}$ & $30 \%$ & $31 \%$ & $30 \%$ \\
\hline & $>\mathrm{RM} 1.5 \mathrm{~m}-\mathrm{RM} 3 \mathrm{~m}$ & $22 \%$ & $26 \%$ & $26 \%$ \\
\hline & >MYR3m & $0 \%$ & $1 \%$ & $3 \%$ \\
\hline 2 & Investors & & & \\
\hline \multirow[t]{5}{*}{$\mathrm{i}$} & Investor Age & & & \\
\hline & Below 35 & $47 \%$ & $46 \%$ & $46 \%$ \\
\hline & $35-45$ & $30 \%$ & $31 \%$ & $31 \%$ \\
\hline & $46-55$ & $13 \%$ & $13 \%$ & $13 \%$ \\
\hline & $>55$ & $10 \%$ & $10 \%$ & $10 \%$ \\
\hline
\end{tabular}


ii Types of Investors

$\begin{array}{lrrr}\text { Retail } & 59 \% & 60 \% & 59 \% \\ \text { Sophisticated } & 21 \% & 19 \% & 19 \% \\ \text { Business Angel } & 18 \% & 19 \% & 20 \% \\ \text { Institutional } & 2 \% & 2 \% & 2 \%\end{array}$

Source: Securities Commission Malaysia (2020)

Table 6 displays the P2P accomplishments as of $31^{\text {st }}$ March, $30^{\text {th }}$ June and $30^{\text {th }}$ September, 2020. Under P2P, the fundraisers offer to pay the investors the principal they borrow and the interest they have been promised. From the table, we can see that P2P platforms have conducted more campaigns than the ECF platforms. The amount raised via P2P shows more than RM900 million. This involves 2,502 fundraisers and more than 13,000 successful campaigns. In terms of allocation, $73 \%$ represents an investment amount of RM50,000 and below. Additionally, $88 \%$ of the investors were retail investors and $62 \%$ of them were below 35 years of age.

Table 6: P2P lending crowdfunding statistics from March 2020 to September 2020

\begin{tabular}{|c|c|c|c|c|}
\hline \multicolumn{2}{|r|}{ P2P Lending Crowdfunding } & \multicolumn{3}{|c|}{ Crowdfunding Statistics as of $30^{\text {th }}$} \\
\hline & & \multirow[t]{2}{*}{ March 2020} & \multirow[t]{2}{*}{ June 2020} & \multirow[t]{2}{*}{ Sept 2020} \\
\hline 1 & Campaigns and Issuers & & & \\
\hline $\mathrm{i}$ & Successful Campaigns & 9,989 & 10,824 & 13,039 \\
\hline ii & Amount Raised (MYR) & 738.99 mil & $798.32 \mathrm{mil}$ & $921.83 \mathrm{mil}$ \\
\hline iii & Successful Issuers & 2,100 & 2,231 & 2,502 \\
\hline \multirow[t]{4}{*}{ iv } & Distribution & & & \\
\hline & RM50,000 and below & $72 \%$ & $71 \%$ & $73 \%$ \\
\hline & $>$ RM50k - RM200k & $20 \%$ & $21 \%$ & $20 \%$ \\
\hline & $>$ RM200k & $8 \%$ & $8 \%$ & $7 \%$ \\
\hline 2 & Investors & & & \\
\hline \multirow[t]{5}{*}{$\mathrm{i}$} & Investor Age & & & \\
\hline & Below 35 & $63 \%$ & $63 \%$ & $62 \%$ \\
\hline & $35-45$ & $24 \%$ & $24 \%$ & $24 \%$ \\
\hline & $46-55$ & $9 \%$ & $9 \%$ & $9 \%$ \\
\hline & $>55$ & $4 \%$ & $4 \%$ & $5 \%$ \\
\hline \multirow[t]{5}{*}{ ii } & Types of Investors & & & \\
\hline & Retail & $95 \%$ & $88 \%$ & $88 \%$ \\
\hline & Sophisticated & $4 \%$ & $4 \%$ & $4 \%$ \\
\hline & Business Angel & 0 & $8 \%$ & $8 \%$ \\
\hline & Institutional & $1 \%$ & 0 & 0 \\
\hline
\end{tabular}

Source: Securities Commission Malaysia (2020) 
Indirectly, Table 5 and Table 6 above illustrate the potential of finance-based crowdfunding as an alternative means of entrepreneurial funding for SMEs in Malaysia, especially in the current pandemic. Further, to gain more information about the financial-based crowdfunding in Malaysia, this study zoomed in on PitchIN, which is the most popular ECF platform in Malaysia. It runs both a rewardbased and ECF crowdfunding platform.

PitchIN has dominated ECF funding campaign scene so far in terms of amounts raised, number of ventures assisted, and investors' participation. In comparison with other platforms, PitchIN provides more inputs to increase stakeholders' interest and improve stakeholders' trust. This is one of the reasons why many fundraisers and investors have approached PitchIN to ask them to raise and to offer funds respectively.

\section{Firms that Successfully Launched Projects on the ECF Platform}

Securities Commission Malaysia (2020), statistically reported the number of firms successfully launching their projects on the platforms as at September, 2020. However, the reports show that hardly 5,000 ventures' participations. Table 7 represents the firms that managed to launch their campaigns on PitchIN during the MCO.

25 out of 27 successful ventures involved business activities relating to technology. In fact, the food and beverage (FB) ventures also use applications such as online orders and reservations. According to Battaglia et al. (2020), technology-related and research and development $(\mathrm{R} \& \mathrm{D})$ industries were the most investor financed industries during COVID-19 pandemic. Table 7 also shows the most common information displayed on the platform during the campaigns.

They are founder and TMT background, the financial information, business model and updates related to ongoing campaigns. As mentioned earlier, financial information. The financial info displayed by the entrepreneurs influence the funders' intention to invest in the project (Di Pietro et al., 2020). The financial info showed the direction of the ventures upon completion of the project (Fanea-Ivanovici, 2018).

Meanwhile, ventures' human capital impact on campaign success has shown mixed findings. According to Ahlers et al. (2015), as the founder/TMT is the proxy of the ventures, the post graduate education level significantly impacts the success of campaigns. Not only educational background, the experience of the entrepreneur seems to positively relate to the funding success (Piva \& Rossi-Lamastra, 2018). However, Lim and Busenitz (2020) argue that business educational background in university and entrepreneurs' experience in big firms do not influence the campaign success.

But, the experience related to small ventures has a positive impact on funding success. Further, Salomon (2016) shares that the emergence of crowdfunding as an innovative way to finance a new project employs a business model that is different from the venture capitalists' (VC's) traditional business model. This explains why the traditional business model is incompatible with the current mainstream business model. According to Löher et al. (2018), quality financial information displayed by the entrepreneur is reflected in their business model, thus, it shows how confident they are of their project campaigns. The ability of the entrepreneurs to provide transparent and continuous campaign updates increases the campaign's genuineness and thus raises the trust level among funders and consequently improves their participation (Mejia et al., 2019). Entrepreneurs able to approach and launch their project campaigns on the platforms due to their spirit of bricolage that makes them capitalise on every possible investment and business opportunity especially in times of crisis (Tsilika et al., 2020). 
Table 7: Firms successfully launched campaigns on ECF platform

\begin{tabular}{|c|c|c|c|c|c|c|}
\hline \multirow[t]{2}{*}{ Ventures } & \multicolumn{2}{|c|}{$\begin{array}{l}\text { Business Activity } \\
\text { Financial Info }\end{array}$} & \multicolumn{4}{|c|}{ Costly Signals } \\
\hline & Financial In & & $\begin{array}{c}\text { Founder/ } \\
\text { TMT } \\
\text { Background }\end{array}$ & $\begin{array}{c}\text { Business } \\
\text { Model }\end{array}$ & $\begin{array}{c}\text { Updates } \\
\text { during } \\
\text { Campaigns } \\
\end{array}$ & \\
\hline Sentuh Sinergi & Digital Platform & Tech & $\sqrt{ }$ & $\sqrt{ }$ & $\sqrt{ }$ & $\sqrt{ }$ \\
\hline Far Capital & $\begin{array}{l}\text { Digital Infrastructure } \\
\text { Provider }\end{array}$ & Tech & $\sqrt{ }$ & $\sqrt{ }$ & $\sqrt{ }$ & $\sqrt{ }$ \\
\hline $\begin{array}{l}\text { Smart Security } \\
\text { Solutions }\end{array}$ & $\begin{array}{l}\text { Digital Smart Lock } \\
\text { Systems }\end{array}$ & Tech & $\sqrt{ }$ & $\sqrt{ }$ & $\sqrt{ }$ & $\sqrt{ }$ \\
\hline Brick House & $\begin{array}{l}\text { Café, Catering, Event } \\
\text { Management }\end{array}$ & FB & $\sqrt{ }$ & $\sqrt{ }$ & $\sqrt{ }$ & $\sqrt{ }$ \\
\hline $\begin{array}{l}\text { Newleaf Eco } \\
\text { Development }\end{array}$ & $\begin{array}{l}\text { Durian Massive } \\
\text { Plantation }\end{array}$ & Agriculture & $\sqrt{ }$ & $\sqrt{ }$ & $\sqrt{ }$ & $\sqrt{ }$ \\
\hline Simply Giving & $\begin{array}{l}\text { Platform Fundraising } \\
\text { for Social Enterprise }\end{array}$ & Tech & $\sqrt{ }$ & $\sqrt{ }$ & $\sqrt{ }$ & $\sqrt{ }$ \\
\hline $\begin{array}{l}\text { MAHSA } \\
\text { Healthcare }\end{array}$ & Healthcare & Healthcare & $\sqrt{ }$ & $\sqrt{ }$ & $\sqrt{ }$ & $\sqrt{ }$ \\
\hline Yin's Sourdough & Food \& Beverage (FB) & FB & $\sqrt{ }$ & $\sqrt{ }$ & $\sqrt{ }$ & $\sqrt{ }$ \\
\hline RentGuard & $\begin{array}{l}\text { Platform-Digital } \\
\text { Property }\end{array}$ & Tech & $\sqrt{ }$ & $\sqrt{ }$ & $\sqrt{ }$ & $\sqrt{ }$ \\
\hline Policy Street & Insurance Technology & Tech & $\sqrt{ }$ & $\sqrt{ }$ & $\sqrt{ }$ & $\sqrt{ }$ \\
\hline VMO & Platform-Event & Tech & $\sqrt{ }$ & $\sqrt{ }$ & $\sqrt{ }$ & $\sqrt{ }$ \\
\hline Newswav & Platform-AI \& BD & Tech & $\sqrt{ }$ & $\sqrt{ }$ & $\sqrt{ }$ & $\sqrt{ }$ \\
\hline Everpeaks & E-commerce & Tech & $\sqrt{ }$ & $\sqrt{ }$ & $\sqrt{ }$ & $\sqrt{ }$ \\
\hline SecondLife & $\begin{array}{l}\text { Technology/ } \\
\text { e-commerce }\end{array}$ & Tech & $\sqrt{ }$ & $\sqrt{ }$ & $\sqrt{ }$ & $\sqrt{ }$ \\
\hline Speedrent & Platform-rent property & Tech & $\sqrt{ }$ & $\sqrt{ }$ & $\sqrt{ }$ & $\sqrt{ }$ \\
\hline Carpedia & Platform-gig income & Tech & $\sqrt{ }$ & $\sqrt{ }$ & $\sqrt{ }$ & $\sqrt{ }$ \\
\hline Regov Tech & Bitcoin & Tech & $\sqrt{ }$ & $\sqrt{ }$ & $\sqrt{ }$ & $\sqrt{ }$ \\
\hline Superceed & Artificial Intelligence & Tech & $\sqrt{ }$ & $\sqrt{ }$ & $\sqrt{ }$ & $\sqrt{ }$ \\
\hline Airuphere & $\begin{array}{l}\text { Platform-Sport } \\
\text { Organizer }\end{array}$ & Tech & $\sqrt{ }$ & $\sqrt{ }$ & $\sqrt{ }$ & $\sqrt{ }$ \\
\hline Deemples & Golfer Platform & Tech & $\sqrt{ }$ & $\sqrt{ }$ & $\sqrt{ }$ & $\sqrt{ }$ \\
\hline Talent Ap Mgmt & $\begin{array}{l}\text { Marketing Solution } \\
\text { Provider }\end{array}$ & Tech & $\sqrt{ }$ & $\sqrt{ }$ & $\sqrt{ }$ & $\sqrt{ }$ \\
\hline NU Vending & Automation & Tech & $\sqrt{ }$ & $\sqrt{ }$ & $\sqrt{ }$ & $\sqrt{ }$ \\
\hline
\end{tabular}




\begin{tabular}{lllllll}
\hline SERV & Vehicle Super App & Tech & $\sqrt{ }$ & $\sqrt{ }$ & $\sqrt{ }$ & $\sqrt{ }$ \\
MAHSA Nexgen & One Stop Digital & Tech & $\sqrt{ }$ & $\sqrt{ }$ & $\sqrt{ }$ & $\sqrt{ }$ \\
& Platform & & & & & \\
Kosumy & Cloud Training & Tech & $\sqrt{ }$ & $\sqrt{ }$ & $\sqrt{ }$ \\
& Platform & & & & $\sqrt{ }$ & $\sqrt{ }$ \\
Accos & E-Commerce & Tech & $\sqrt{ }$ & $\sqrt{ }$ & $\sqrt{ }$ & $\sqrt{ }$ \\
JTel Marketing & Rental Water Machine & Service & $\sqrt{ }$ & $\sqrt{ }$ & $\sqrt{ }$ \\
\hline Total=27 ventures & & & & & & \\
\hline
\end{tabular}

Source: Author Illustration

\section{PitchIN and ECF Activities amidst Covid-19}

Table 8 below shows the success campaigns activities conducted by PitchIN during the COVID-19 outbreak until $18^{\text {th }}$ November, 2020. It shows that PitchIN has assisted ventures to obtain funding. A total of 22 successful campaigns were launched during the crisis involving more than 1,190 investors and the cumulative amount raised was more than RM37 million. Policy Street recorded the highest success campaign while the lowest amount raised was RM250,500 by Airuphere.
The highest shares offered was $25.17 \%$ by Everpeak, an e-commerce platform, and the smallest percentage of ownership was $1.51 \%$ offered by Far Capital, a digital infrastructure provider.

In terms of investors' participation the highest recorded was 274 and lowest was 3. Surprisingly, the single largest investment was in fact three investments worth RM1 million and above from a single investor. The campaigns also reflected the dominance of technologyrelated activities or industries on the investment and financing market.

Table 8: PitchIN platform's success campaigns during COVID-19

\begin{tabular}{|c|c|c|c|c|c|}
\hline $\begin{array}{l}\text { PitchIN Platforms } \\
\text { Sdn Bhd }\end{array}$ & Business Activity & $\begin{array}{c}\text { Amount } \\
\text { Raised } \\
\text { (RM) }\end{array}$ & $\begin{array}{c}\text { Shares } \\
\text { Offered } \\
(\%)\end{array}$ & $\begin{array}{c}\text { No. of } \\
\text { Investors }\end{array}$ & $\begin{array}{l}\text { Single Larges } \\
\text { Investment } \\
\text { (RM) }\end{array}$ \\
\hline Sentuh Sinergi & Digital Platform & 734,400 & 8.16 & 74 & 221,400 \\
\hline Far Capital & $\begin{array}{l}\text { Digital Infrastructure } \\
\text { Provider }\end{array}$ & 263,500 & 1.51 & 3 & 250,000 \\
\hline $\begin{array}{l}\text { Smart Security } \\
\text { Solutions }\end{array}$ & $\begin{array}{l}\text { Digital Smart Lock } \\
\text { Systems }\end{array}$ & 684,250 & 10.24 & 34 & 226,100 \\
\hline Brick House & $\begin{array}{l}\text { Café, Catering, Event } \\
\text { Management }\end{array}$ & $3,000,000$ & 6.98 & 9 & $1,000,000$ \\
\hline $\begin{array}{l}\text { Newleaf Eco } \\
\text { Development }\end{array}$ & $\begin{array}{l}\text { Durian Massive } \\
\text { Plantation }\end{array}$ & 920,000 & $\mathrm{~N} / \mathrm{A}$ & 51 & 270,000 \\
\hline Simply Giving & $\begin{array}{l}\text { Platform Fundraising for } \\
\text { Social Enterprise }\end{array}$ & 317,912 & 10.99 & 9 & 129,412 \\
\hline MAHSA Healthcare & Healthcare & $3,000,000$ & 10.71 & 8 & $1,000,000$ \\
\hline Yin's Sourdough & $\mathrm{F} \& \mathrm{~B}$ & $1,139,468$ & 15 & 59 & 220,806 \\
\hline RentGuard & Platform-Digital Property & 644,600 & 4.63 & 107 & 165,600 \\
\hline
\end{tabular}




\begin{tabular}{llcccc}
\hline Policy Street & Insurance Technology & $5,280,657$ & 11.71 & 274 & 998,058 \\
VMO & Platform-Event & $2,085,052$ & 9.10 & 24 & 692,464 \\
Newswav & Platform-AI \& BD & $1,520,178$ & 18.74 & 7 & 550,016 \\
Everpeaks & E-commerce & 941,000 & 25.17 & 48 & 500,000 \\
SecondLife & Technology/e-commerce & 268,800 & 9.11 & 14 & 150,000 \\
Speedrent & Platform-rent Property & $2,592,962$ & 10.27 & 106 & 639,744 \\
Carpedia & Platform-gig Income & 552,500 & 15 & 87 & 139,400 \\
Regov Tech & Bitcoin & $2,830,423$ & 8.4 & 132 & 895,752 \\
Superceed & Artificial Intelligence & $3,110,555$ & 7.29 & 31 & 998,296 \\
Airuphere & Platform-Sport Organizer & 250,500 & 9.04 & 9 & 100,500 \\
Deemples & Golfer Platform & $1,440,000$ & 16.78 & 59 & 450,000 \\
Talent Ap Mgmt & Marketing Solution & $3,000,800$ & 25.05 & 19 & $1,038,400$ \\
& Provider & & & & \\
NU Vending & Automation & $2,457,200$ & 10.53 & 27 & 736,400 \\
\hline & Total & $\mathbf{3 7 , 0 3 4 , 7 5 7}$ & & $\mathbf{1 , 1 9 1}$ & \\
\hline
\end{tabular}

Source: PitchIN (2020)

Meanwhile, Table 9 below presents the ongoing campaigns. So far, there are five campaigns and out of the five, four are technology-based campaigns. MAHSA Nexgen offers $16.67 \%$ of the ownership. It has exceeded its target funding goal by $33.53 \%$ and is waiting for 8 more days to complete the campaign.

To date, more than RM2 million has been raised from 10 investors with the largest single investment recording RM500,000. Accos, an e-commerce provider, offered $48.78 \%$ stakes and is nearing its funding target $(99.80 \%)$ which should end in another 15 days and has managed to attract nine investors. SERV, a new take off campaign, offers $10 \%$ shares and has another 45 days to complete the campaign.
However, these campaigns will only be regarded as successful when $100 \%$ of the funding goal has been achieved and the cooling off period of 6 days following the end of the campaigns has been met, as ECF investors may withdraw the full amount of their investment before the cooling off period ends.

In addition, if there is any material adverse change relating to an issuer, the investors must be notified of such change. The investors will be given the option to withdraw their investment if they choose to do so within 14 days after the said notification (Securities Commission Malaysia, 2015). 
Table 9: PitchIN platform's ongoing campaigns during COVID-19

\begin{tabular}{|c|c|c|c|c|c|c|c|}
\hline $\begin{array}{l}\text { PitchIN } \\
\text { Platforms } \\
\text { Sdn Bhd }\end{array}$ & $\begin{array}{l}\text { Type of } \\
\text { Industry }\end{array}$ & $\begin{array}{c}\text { Funding } \\
\text { Percentage }\end{array}$ & $\begin{array}{c}\text { Days to } \\
\text { Complete the } \\
\text { Campaign }\end{array}$ & $\begin{array}{l}\text { Amount } \\
\text { Raised } \\
\text { (RM) }\end{array}$ & $\begin{array}{c}\text { Shares } \\
\text { Offered } \\
(\%)\end{array}$ & $\begin{array}{c}\text { No. of } \\
\text { Investors }\end{array}$ & $\begin{array}{c}\text { Larges } \\
\text { Investment } \\
\text { (RM) }\end{array}$ \\
\hline SERV & $\begin{array}{l}\text { Vehicle } \\
\text { Super App }\end{array}$ & $13.32 \%$ & 45 & 133,200 & 10.00 & 26 & 18,000 \\
\hline $\begin{array}{l}\text { MAHSA } \\
\text { Nexgen }\end{array}$ & $\begin{array}{l}\text { One Stop } \\
\text { Digital } \\
\text { Platform }\end{array}$ & $133.53 \%$ & 8 & $2,003,000$ & 16.67 & 10 & 500,000 \\
\hline Kosumy & $\begin{array}{l}\text { Cloud } \\
\text { Training } \\
\text { Platform }\end{array}$ & $83 \%$ & 38 & 415,000 & 19.35 & 11 & 100,000 \\
\hline Accos & E-Commerce & $99.80 \%$ & 15 & 998,040 & 48.78 & 9 & 300,000 \\
\hline $\begin{array}{l}\text { JTel } \\
\text { Marketing }\end{array}$ & $\begin{array}{l}\text { Rental Water } \\
\text { Machine }\end{array}$ & $67.77 \%$ & 25 & 203,300 & 9.52 & 13 & 51,300 \\
\hline
\end{tabular}

Source: PitchIN (2020)

In year 2020, PitchIN made history after securing the target amount of MYR100 million which was raised from its equity crowdfunding activities. According to its chief strategy officer, the new announcement of fundraising limits early this year has encouraged entrepreneurs to seek their funding via the ECF platform.

Additionally, the increase in fundraising limits and the introduction of MyCIF as an additional financial assistance for eligible ECF and P2P campaigns also contributed to PitchIN's success. Additionally, the recent budget 2021 announcement of tax rebates for ECF investments and the agenda of PitchIN's secondary market are projected to attract more potential investors (MSME Admin, 2020).

\section{Conclusion and Discussion}

The COVID-19's impact on entrepreneurial ventures vary depending on various factors including the ventures' mission and vision, the founder's leadership, the demography of the founder and top management team, and the ventures' financial health. All entrepreneurial sectors, especially SMEs and start-ups, have been badly affected by the pandemic (Brown \&
Rocha, 2020), and the government could take steps to reduce anxiety and panic in these sectors (Sahadevan \& Bhagat, 2020).

Amazingly, one of the positive outcomes of the pandemic is the increased spirit of social entrepreneurship, in which ideal collaboration with the government and other social institutions and businesses is realised, and skills, knowledge and community networks have shown their virtuous characters in making the impossible possible (Hidayat et al., 2020). Accordingly, studies have shown that crowdfunding as an effective response mechanism in the current COVID-19 pandemic business climate (Mejia et al., 2019).

Meanwhile, there are several common entrepreneurial responses due to the pandemic. For instance, in order to remain in existence, capital injection is needed to pay for operating expenses. If the venture chooses to exercise costcutting regimes such as retrenchment or use of lower grade raw material, these will affect the overall performance of the venture (Wenzel et al., 2020). Another solution is to withdraw from the market and restart the new start-up or venture that is resilient and fit with the present situation (Deschryvere et al., 2020). 
Despite the COVID-19 conundrum, financial-based crowdfunding providers are actively conducting fund-raising activities as usual (Brown et al., 2020). This is the privilege that does not count under the traditional banking and financial institutions' system (Bruton et al., 2015). Entrepreneurs who constantly expose their costly signals will eventually attract investors or potential funders to visit the campaigns launched on the platforms. The ability of fundraisers to provide transparent and continuous campaign updates will increase the campaign's genuineness and thus raise the trust level among donors. However, the platform's accreditation is a donor's concern. Hence, fundraisers using non-accredited platforms need to double their effort in providing the campaign's status to lock the donor's attention (Mejia et al., 2019).

Nevertheless, the costly signals displayed by the financial-based platforms themselves will attract more campaigns from fundraisers and more investments from funders. Thus, under the financial-based crowdfunding umbrella, both parties (i.e. the entrepreneurs and the platform providers) need to transmit their costly signals as the investors rely on those signals. These will increase the investment chances (Di Pietro et al., 2020). The costly signals related to crowdfunding such as the platform's popularity and COVID-19 policies will also attract the investors' participation in a crowdfunding activity (Moine \& Papiasse, 2020).

Even though investors actively participate in equity crowdfunding campaigns during the crisis, the number is decreasing (Battaglia et al., 2020; Brown et al., 2020). Moreover, investors do not merely invest based on the percentage of shares offered (Buell et al., 2020). Conversely, strategies that reflect firm profitability $(\mathrm{Hu}$ et al., 2018) will likely influence the investors' trust and participation (Buell et al., 2020), especially during the crisis (Mejia et al., 2019). One thing for sure, crowdfunding is not simply about acquiring money from investors, but also requires the experience and expertise of the fund provider that will benefit the venture more.
It revolves around the "business valuation" and "concept validation". The venture's previous successful round in fundraising from the crowdfunding campaign is an advantage which will secure the high net-worth and farreaching investors' interest (Brown et al., 2020). Nevertheless, the literature of entrepreneurship suggests the importance of costless signals. According to Chan and Parhankangas (2017), the costless signals in crowdfunding scenarios may be helpful if there is limited information available (Lin et al., 2013), when it involves inexperienced investors (Loewenstein et al., 2014), and in a new marketplace where the reputable interactive standards are zero (Danilov \& Sliwka, 2017).

This study is one of the few studies which explored the importance of costly signals and entrepreneurial bricolage under the financialbased crowdfunding context in Malaysia during the COVID-19 pandemic. Entrepreneurial funding via financial-based crowdfunding is still considered a new emerging phenomenon in the country. Thus, this study adds to the existing literature on crowdfunding in the Malaysian setting. Unfortunately, this study has its own limitations. Firstly, limited information on the ECF recipients' websites. Secondly, restricted information provided by the platforms providers in their websites. As a result, this study is unable to reveal the entirety of finance-based crowdfunding situation in Malaysia at the moment .

This study recommends for future research using experimental analysis to provide the latest empirical findings. Firstly, to examine the portfolio of costly signals which constitute the fundraising campaign success. The signals include but are not restricted to financial information (Di Pietro et al., 2020; Chen et al., 2017; Shahzad et al., 2019), founders' (Lim \& Busenitz, 2020; Bernstein et al., 2017; Ahlers et al., 2015) and TMTs' (Baum \& Silverman, 2004) backgrounds, business models (Lukkarinen et al., 2016; Ahlers et al., 2016), campaign's updates (Mollick, 2014), practices employed (Bae et al., 2017), social networks association 
(Liao et al., 2015; Dessalles, 2014), platforms (Plummer et al., 2016; Helmer, 2014) and investors' affiliation (Kleinert et al., 2020; Kim \& Viswanathan, 2019; Woköck, 2019; Vismara, 2018; Courtney et al., 2017) and their impact on the ventures' fundraising performance.

Secondly, to investigate entrepreneurial bricolage and attitudes towards the performance of the ventures.

Thirdly, to investigate the importance of costly signals and entrepreneurial bricolage from the perspective of finance-based crowdfunding platform providers and lastly, the impact of the business analytics (Devera La Rosa, 2017; Ortiz et al., 2019) in providing quality signals from both financial-based crowdfunding players; the firm and the platform and its impacts on their performances.

The sustainability of finance-based crowdfunding ecosystem in Malaysia depends on the sustainability of the fundraisers (entrepreneurs) and the platform providers. Therefore, the policy measures by the government should not be restricted merely to eliminate the burden of cash flows but should also include the wider space of the entrepreneurial landscape for speedy recuperation and progress (Kuckertz et al., 2020).

The government needs to have real-time information so that any uncertainty awaiting the entrepreneurs could be managed accordingly (Brown \& Rocha, 2020).

\section{References}

Ahlers, G. K., Cumming, D., Günther, C., \& Schweizer, D. (2015). Signaling in equity crowdfunding. Entrepreneurship Theory and Practice, 39(4), 955-980.

Anderson, J., \& Kupp, M. (2008). Serving the poor: Drivers of business model innovation in mobile. Info, 10(1), 5-12.

Bae, J., Kim, S. J., \& Oh, H. (2017). Taming polysemous signals: The role of marketing intensity on the relationship between financial leverage and firm performance. Review of Financial Economics, 33, 29-40.

Baeck, P., \& Collins, L. (2013). Working the Crowd: A short Guide to crowdfunding and how it can work for you. London: Nesta.

Baker, T., \& Nelson, R. E. (2005). Creating something from nothing: Resource construction through entrepreneurial bricolage. Administrative Science Quarterly, 50(3), 329-366.

Bapna, R., Gupta, A., Rice, S., \& Sundararajan, A. (2017). Trust and the strength of ties in online social networks: an exploratory field experiment. Mis Q., 41(1), 115-130.

Battaglia, F., Busato, F., \& Manganiello, M. (2020). Equity crowdfunding: Brave market or safe haven for the crowd during the COVID-19 crisis? Available at SSRN 3666021.

Baum, J. A., \& Silverman, B. S. (2004). Picking winners or building them? Alliance, intellectual, and human capital as selection criteria in venture financing and performance of biotechnology startups. Journal of Business Venturing, 19(3), 411436.

Beck, R. (2017). Crowdinvesting: Die Investition der Vielen. Börsenbuchverlag.

Behl, A., Dutta, P., Sheorey, P., \& Singh, R. K. (2020). Examining the role of dialogic Communication and trust in donation-based crowd funding tasks using information quality perspective. The TQM Journal. https://doi.org/10.1108/TQM-06-20200139

Bernstein, S., Korteweg, A., \& Laws, K. (2017). Attracting early stage investors: Evidence from a randomized field experiment. The Journal of Finance, 72(2), 509-538.

Bhattacharya, U., \& Dittmar, A. (2003). Costless versus costly signaling: Theory and evidence from share repurchases. Seminar Paper at Alabama, Humboldt, Frankfurt, Illinois, Indiana, INSEAD, Norwegian 
School of Management, Notre Dame, Penn State and Pittsburgh.

Biancone, P. P., Secinaro, S., \& Kamal, M. (2019). Crowdfunding and Fintech: Business model sharia compliant. European Journal of Islamic Finance, 12, 1-9.

Bogle, J. C., \& Sullivan, R. N. (2009). Markets in crisis. Financial Analysts Journal, 65(1), 17-24.

Brown, R., \& Rocha, A. (2020). Entrepreneurial uncertainty during the Covid-19 crisis: Mapping the temporal dynamics of entrepreneurial finance. Journal of Business Venturing Insights, 14, E00174.

Brown, R., Rocha, A., \& Cowling, M. (2020). Financing entrepreneurship in times of crisis: Exploring the impact of COVID-19 on the market for entrepreneurial finance in the United Kingdom. International Small Business Journal, 38(5), 380-390.

Bruton, G., Khavul, S., Siegel, D., \& Wright, M. (2015). New financial alternatives in seeding entrepreneurship: Microfinance, crowdfunding, and peer to peer innovations. Entrepreneurship Theory and Practice, 39(1), 9-26.

Brzozowska, B. (2013). Crowdfunding and crowdsourcing: New challenges for the visual documentation of city cultures. Cultural Studies Review/Przegląd Kulturoznawczy, 4(18), 301-310.

Chan, C. R., \& Parhankangas, A. (2017). Crowdfunding innovative ideas: How incremental and radical innovativeness influence funding outcomes. Entrepreneurship Theory and Practice, 41(2), 237-263.

Chang, F., \& Webster, C. M. (2019). Effects of network bricolage on entrepreneurs' resource creation. Academy of Management Proceedings, 2019(1), 10137.

Chen, Q., Zheng, S., \& Mou, W. (2017). The relationship between financial reporting quality and investment efficiency. Paper presented at the $3^{\text {rd }}$ International Conference on Economics, Management, Law and Education (EMLE 2017). Atlantis Press.

Courtney, C., Dutta, S., \& Li, Y. (2017). Resolving information asymmetry: Signaling, endorsement, and crowdfunding success. Entrepreneurship Theory and Practice, 41(2), 265-290.

Cumming, D., \& Johan, S. (2017). Chapter 5: Crowdfunding and entrepreneurial internationalization. In N. Dai, \& D. Siegel (Eds.), The world scientific reference on entrepreneurship (Vol. 2): Entrepreneurial finance-managerial and policy implications (pp. 109-126). The World Scientific Publishers.

Danilov, A., \& Sliwka, D. (2017). Can contracts signal social norms? Experimental evidence. Management Science, 63(2), 459-476. https://doi.org/10.1287/mnsc.2015.2336

Desa, G., \& Basu, S. (2013). Optimization or Bricolage? Overcoming resource constraints in global social entrepreneurship. Strategic Entrepreneurship Journal, 7(1), 26-49.

Deschryvere, M., Mikkola, M., \& Conn, S. (2020). On the structural barriers to public innovation support for SMEs and the opportunity COVID-19 can offer to overcome these barriers. Journal of Innovation Management, 8(2), 16-25.

Dessalles, J. L. (2014). Optimal investment in social signals. Evolution, 68(6), 1640-1650.

Devera La Rosa, A. P. (2017). "Business Intelligence and Analytics applied to a collaboration platform".

Di Domenico, M., Haugh, H., \& Tracey, P. (2010). Social bricolage: Theorizing social value creation in social enterprises. Entrepreneurship Theory and Practice, 34(4), 681-703.

Di Pietro, F., Grilli, L., \& Masciarelli, F. (2020). Talking about a revolution? Costly and costless signals and the role of innovativeness in equity crowdfunding. Journal of Small Business Management, 1-32. 
Domínguez, D. G., García, D., Martínez, D. A., \& Hernandez-Arriaga, B. (2020). Leveraging the power of mutual aid, coalitions, leadership, and advocacy during Covid-19. American Psychologist, 75(7), 909-918.

Estrin, S., Gozman, D., \& Khavul, S. (2018). The evolution and adoption of equity crowdfunding: Entrepreneur and investor entry into a new market. Small Business Economics, 1-15.

Fanea-Ivanovici, M. (2018, June). Transparency of financial information on crowdfunding platforms-a prerequisite for successful funding campaigns. In International conference knowledge-based organization (Vol. 24, No. 2, pp. 37-42). Sciendo.

Farah Adilla. (2017, Nov. $\left.6^{\text {th }}\right)$. Govt establishing co-investment fund (CIF). New Straits Times. https://www.nst. com.my/business/2017/11/299864/govtestablishing-co-investment-fund-cif

Fong, V. (2020, Apr. 16 $\left.{ }^{\text {th }}\right)$. Crowdfunding: Securities Commission raises equity crowdfunding fundraising limits to RM 10 million. Fintech News Malaysia. https:// fintechnews.my/23418/crowdfundingmalaysia/securities-commission-raisesequity-crowdfunding-fundraising-limits-torm-10-million/

Freedman, D. M., \& Nutting, M. R. (2015). Equity crowdfunding for investors: a guide to risks, returns, regulations, funding portals, due diligence, and deal terms. John Wiley \& Sons.

Garud, R., \& Karnøe, P. (2003). Bricolage versus breakthrough: Distributed and embedded agency in technology entrepreneurship. Research Policy, 32(2), 277-300.

Gierczak, M. M., Bretschneider, U., Haas, P., Blohm, I., \& Leimeister, J. M. (2015). Crowdfunding: Outlining the new era of fundraising. In O. Gajda, \& D. Brüntje (Eds.), Crowdfunding in Europe - State of the art in theory and practice (pp. 7-23). Cham: Springer Science + Business Media.
Gierczak, M. M., Bretschneider, U., Haas, P., Blohm, I., \& Leimeister, J. M. (2016). Crowdfunding: Outlining the new era of fundraising. In O. Gajda, \& D. Brüntje (Eds.), Crowdfunding in Europe - State of the art in theory and practice (pp. 7-23). Springer International Publishing.

Gomez, O. C. (2020, May 4 $\left.{ }^{\text {th }}\right)$. Personal Wealth. The Wall: SC move a boost for ECF Industry. The Edge Markets. https://www. theedgemarkets.com/article/thewall-scmove-boost-ecf-industry.

Green, A, Tunstall, R. J., \& Peisl, T. (2015). The benefits of crowdfunding for early-stage entrepreneurs: between finance gap and democratic involvement. Paper presented at the R\&D Management Conference, 23-26 Jun 2015, Pisa, Italy.

Hagedorn, A., \& Pinkwart, A. (2016). The financing process of equity-based crowdfunding: An empirical analysis. In D. Brüntje \& O. Gajda (Eds.), Crowdfunding in Europe: State of the art in theory and practice (pp. 71-85). Springer International Publishing.

Halme, M., Lindeman, S., \& Linna, P. (2012). Innovation for inclusive business: Intrapreneurial bricolage in multinational corporations. Journal of Management Studies, 49(4), 743-784.

Helmer, J. (2014). 8 ways to cut through the crowdfunding clutter. Entrepreneur, 42(6), 86-90.

Hidayat, S., Dirgantara, T., Kusuma, M. A., Utomo, H., Sudjud, R. W., Rejeki, I. S., ... \& Tjahjono, H. (2020). Lessons learned from rapid development of CPAP ventilator vent-I during Covid-19 pandemic in Indonesia. Journal of Engineering and Technological Sciences, 52(5), 765-778.

Hsu, D. H., \& Ziedonis, R. H. (2013). Resources as dual sources of advantage: Implications for valuing entrepreneurial firm patents. Strategic Management Journal, 34(7), 761781. 
Kariv, D., \& Coleman, S. (2015). Toward a theory of financial bricolage: The impact of small loans on new businesses. Journal of Small Business and Enterprise Development, 22(2), 196-224.

Ketchen Jr, D. J., \& Craighead, C. W. (2020). Research at the intersection of entrepreneurship, supply chain management, and strategic management: Opportunities highlighted by COVID-19. Journal of Management, 46(8), 1330-1341.

Kim, K., \& Viswanathan, S. (2019). The experts in the crowd: The role of experienced investors in a crowdfunding market. Mis Quarterly, 43(2), 347-372.

Kleinert, S., Volkmann, C., \& Grünhagen, M. (2020). Third-party signals in equity crowdfunding: The role of prior financing. Small Business Economics, 54(1), 341-365.

Kuckertz, A., Brändle, L., Gaudig, A., Hinderer, S., Reyes, C. A. M., Prochotta, A., ... \& Berger, E. S. (2020). Startups in times of crisis-a rapid response to the COVID-19 pandemic. Journal of Business Venturing Insights, E00169.

Kuek, S. K. Z. (2020, Aug. 13 $\left.{ }^{\text {th }}\right)$. Personal Wealth. Fintech: First secondary market for P2P financing in Malaysia. The Edge Markets. https://www.theedgemarkets.com/ article/fintech-first-secondary-market-p2pfinancing-malaysia.

Leung, T. Y., Sharma, P., Adithipyangkul, P., \& Hosie, P. (2020). Gender equity and public health outcomes: The COVID-19 experience. Journal of Business Research, 116, 193-198.

Liao, C., Zhu, Y., \& Liao, X. (2015). The role of internal and external social capital in crowdfunding: Evidence from China. Revista De Cercetare Si Interventie Socialâ, 49, 187-204.

Lim, J. Y. K., \& Busenitz, L. W. (2020). Evolving human capital of entrepreneurs in an equity crowdfunding era. Journal of
Small Business Management, 58(1), 106129.

Loewenstein, G., Sunstein, C. R., \& Golman, R. (2014). Disclosure: Psychology changes everything. Annual Review of Economics, 6(1), 391-419. https://doi.org/10.1146/ annureveconomics-080213-041341.

Löher, J., Schneck, S., \& Werner, A. (2018). A research note on entrepreneurs' financial commitment and crowdfunding success. Venture Capital, 20(3), 309-322.

Lukkarinen, A., Teich, J. E., Wallenius, H., \& Wallenius, J. (2016). Success drivers of online equity crowdfunding campaigns. Decision Support Systems, 87, 26-38.

Mahajan, S. (2013). Women entrepreneurship in India. Global Journal of Management and Business Studies, 3(10), 1143-1148.

Mejia, J., Urrea, G., \& Pedraza Martinez, A. J. (2019). Operational transparency on crowdfunding platforms: Effect on donations for emergency response. Production and Operations Management, 28(7), 1773-1791.

Moine, A., \& Papiasse, D. (2020). Evidence from France: How crowdfunding is being used to support the response to Covid-19. LSE European Politics and Policy (EUROPP) blog. https://blogs.lse.ac.uk/ europpblog/2020/04/24/evidence-fromfrance-how-crowdfunding-is-being-usedto-support-the-response-to-covid-19/

Mollick, E. R. (2014). The dynamics of crowdfunding: An exploratory study. Journal of Business Venturing, 29(1), 1-16.

Morse, A. (2015). Peer-to-peer crowdfunding: Information and the potential for disruption in consumer lending. Annual Review of Financial Economics, 7, 463-482.

MSMEAdmin. (2020, Nov. $\left.13^{\text {th }}\right)$. PitchINPowers Past RM100 million Equity Crowdfunding Milestone. https://www.malaysiasme.com. my/pitchin-powers-past-rm100-millionequity-crowdfunding-milestone/ 
Ortiz, J., Young, A., Myers, M., Carbaugh, D., Bedeley, R. T., Chughtai, H., \& Wigdor, A. (2019). Giving voice to the voiceless: The use of digital technologies by marginalized groups.

Pazowski, P., \& Czudec, W. (2014). Economic prospects and conditions of crowdfunding. Human Capital without Borders: Knowledge and Learning for Quality of Life; Proceedings of the Management, Knowledge and Learning International Conference 2014, 1079-1088.

Piva, E., \& Rossi-Lamastra, C. (2018). Human capital signals and entrepreneurs' success in equity crowdfunding. Small Business Economics, 51, 667-686. doi:10.1007/ s11187-017-9950-y

Plummer, L. A., Allison, T. H., \& Connelly, B. L. (2016). Better together? Signaling interactions in new venture pursuit of initial external capital. Academy of Management Journal, 59(5), 1585-1604.

Ramadani, V., Dana, L. P., Sadiku-Dushi, N., Ratten, V., \& Welsh, D. H. (2017). Decision-making challenges of women entrepreneurship in family business succession process. Journal of Enterprising Culture, 25(04), 411-439.

Salomon, V. (2016). Emergent models of financial intermediation for innovative companies: from venture capital to crowdinvesting platforms in switzerland. Venture Capital, 18(1), 21-41.

Securities Commission Malaysia. (2015). Guidelines on Regulation of Markets Under Section 34 of CMSA SC-GL/2-2015. https:// www.sc.com.my/wp-content/uploads/eng/ $\mathrm{html} /$ resources/guidelines/rep/guidelines rep_150210.pdf

Securities Commission Malaysia. (2015). List of Registered Market Operators for ECF. https://www.sc.com.my/digital/equitycrowdfunding/list-of-registered-marketoperators-for-ecf/
Securities Commission Malaysia. (2015). SC Releases New Guidelines to Facilitate Equity Crowdfunding. https://www.sc.com.my/ post_archive/sc-releases-new-guidelinesto-facilitate-equity-crowdfunding/

Securities Commission Malaysia. (2016). Recognized Markets (ECF, P2P and Digital Asset Exchanges). https://www.sc.com.my/ regulation/guidelines/recognizedmarkets/

Securities Commission Malaysia. (2017). Annual Report 2017. https://www.sc.com.my/api/ documentms/download.ashx?Id=097e62ec8464-46a2-A3e0-9cb4ee164ca7

Securities Commission Malaysia. (2018). Annual Report 2018. https://www.sc.com.my/api/ documentms/download.ashx?Id=69b9ad2a13c7-40bf-B0d3-341951a62278

Securities Commission Malaysia. (2020). ECF/ $P 2 P . \quad$ https://www.sc.com.my/analytics/ ecfp2p.

Securities Commission Malaysia. (2020). Guidelines on Recognized Markets (Archive - 5 May 2020). SG - GL/62105. Part F: Additional Requirements Relating to a Recognized Market that is a Crowdfunding Platform. Chapter 13: Equity Crowdfunding Platform., page 25-36. https://www.sc.com.my/ask-aliss\#search/ equity $\% 20$ crowdfuning $\% 20$ platform.

Senyard, J., Baker, T., Steffens, P., \& Davidsson, P. (2011). Bricolage as a path to innovativeness for resource constrained new firms. Journal of Product Innovation Management, 31(2), 211-230.

Shahzad, F., Rehman, I. U., Hanif, W., Asim, G. A., \& Baig, M. H. (2019). The influence of financial reporting quality and audit quality on investment efficiency. International Journal of Accounting \& Information Management, 27(4), 600-614.

Steigenberger, N., \& Wilhelm, H. (2018). Extending signaling theory to rhetorical signals: Evidence from crowdfunding. Organization Science, 29(3), 529-546.

Stenholm, P., \& Renko, M. (2016). Passionate 
bricoleurs and new venture survival. Vanevenhoven, J., Winkel, D., Malewicki, Journal of Business Venturing, 31(5), 595- D., Dougan, W. L., \& Bronson, J. (2011). 611.

Swart, R., \& Milner, M. E. (2015, Nov. 05 $\left.{ }^{\text {th }}\right)$. Crowdfunding a roadmap for Global Solution Networks. Global Solution Networks.

Tsilika, T., Kakouris, A., Apostolopoulos, N., \& Dermatis, Z. (2020). Entrepreneurial bricolage in the aftermath of a shock: Insights from Greek SMEs. Journal of Small Business \& Entrepreneurship, 1-18.

Tuomi, K., \& Harrison, R. T. (2017). A comparison of equity crowdfunding in four countries: Implications for business angels. Strategic Change, 26(6), 609-615. Varieties of bricolage and the process of entrepreneurship. New England Journal of Entrepreneurship, 14(2), 53-66.

Vismara, S. (2018). Information cascades among investors in equity crowdfunding. Entrepreneurship Theory and Practice, 42(3), 467-497.

Wenzel, M., Stanske, S., \& Lieberman, M. B. (2020). Strategic responses to crisis. Strategic Management Journal, 41, V7V18.

Woköck, J. (2019). Business Angel Celebrities - How Investors' Social Media Signaling Supports Resource Acquisition of Early Stage Ventures. https://aisel.aisnet.org/ icis2019/innov_entre/innov_entre/10/ 
